\title{
The role of statin treatment in valvular heart disease: is the jury still out?
}

\author{
Francesco ANTONINI-CANTERIN ${ }^{1}$, MD; Anca D. MATEESCU ${ }^{1,2}, \mathrm{MD}$; Gian Luigi NICOLOSI ${ }^{3}$, MD; \\ Carmen GINGHINA $\breve{2}^{2}, \mathrm{MD}$, PhD; Patrizio LANCELLOTTI ${ }^{4}, \mathrm{MD}$, PhD; Bernard COSYNS ${ }^{5}, \mathrm{MD}, \mathrm{PhD}$; \\ Bogdan A. POPESCU ${ }^{2}, \mathrm{MD}, \mathrm{PhD}$
}

${ }^{1}$ Preventive and Rehabilitative Cardiology, ARC, Azienda Ospedaliera S. Maria degli Angeli, Pordenone, Italy; ${ }^{2}$ Carol Davila University of Medicine and Pharmacy, Prof. Dr. C. C. Iliescu Institute of Cardiovascular Diseases, Bucharest, Romania; ${ }^{3}$ Cardiology Department, ARC, Azienda Ospedaliera S. Maria degli Angeli, Pordenone, Italy; ${ }^{4}$ University of Liège Hospital, GIGA Cardiovascular Sciences, Heart Valve Clinic, Department of Cardiology, CHU Sart Tilman, Liège, Belgium; ${ }^{5}$ Universitair Ziekenhuis Brussels, CHIREC Braine (Braine l’Alleud), Belgium.

Abstract Valvular heart disease (VHD) represents a significant burden within the spectrum of cardiovascular diseases. In recent years, there has been a great interest in finding medical treatments able to slow the progression of VHD. The negative results of several large randomized trials failing to demonstrate a benefit of such therapies, has led to a decrease of interest in this field. However, finding a medical treatment capable of preventing VHD progression is still a hot topic, due to the important clinical implications. We believe that the jury is still out on the debate about the role of statin therapy in VHD, considering also recently published studies providing new information with future implications for the treatment of this disease process. This article gives an overview of the published evidence about the role of hydroxymethylglutaryl coenzyme-A reductase inhibitors on delaying progressive valve dysfunction. A preventive therapy, which could influence not only the haemodynamic progression of valve disease, but also the cardiovascular outcome, is warranted. Large, prospective, randomized trials are needed to properly evaluate the role of statins in the early stages of valvular heart disease.

Keywords Valvular heart disease-progression-statin treatment.

\section{INTRODUCTION}

With an estimated prevalence of up to $12 \%$ of adults over the age of 75 years, valvular heart disease (VHD) represents a significant burden within the spectrum of cardiovascular diseases ${ }^{1}$. In the past, VHD was typically caused by rheumatic heart disease, which remains a significant contributor in developing countries ${ }^{2}$. However, in industrialized countries the prevalence of rheumatic disease has fallen substantially and the main cause of VHD is now represented by 'degenerative' disease. For patients with symptomatic, severe VHD, cardiac

Address for correspondence:

Assoc. Prof. Bogdan A. Popescu, MD, PhD, FESC, FACC, "Carol Davila" University of Medicine and Pharmacy - Euroecolab, "Prof. Dr. C.

C. Iliescu"Institute of Cardiovascular Diseases, Sos. Fundeni 258, sector 2, 022328 Bucharest, Romania.

E-mail: bogdan.a.popescu@gmail.com

Received 28 March 2013; revision accepted for publication 21 May 2013. surgery is recommended while conventional medical treatment is reserved for symptoms' control in inoperable cases ${ }^{2}$. In recent years, there has been a great interest in finding medical treatments able to slow the progression of VHD. The negative results of several large randomized trials failing to demonstrate a benefit of such therapies, led to a decrease of interest in this field.

In this article we provide an overview of the published evidence about the role of hydroxymethylglutaryl coenzyme-A reductase inhibitors (statins) on delaying progressive valve dysfunction.

\section{STATINS AND PROGRESSION OF CALCIFIC AORTIC VALVE STENOSIS}

\section{Epidemiology and natural history of calcific aortic stenosis}

Aortic stenosis (AS) is the most common isolated valve lesion nowadays, representing approximately $34 \%$ of patients with $\mathrm{VHD}^{3}$. It affects $3-7 \%$ of the population 
above 65 years $^{1-3}$. Moreover, its prevalence is increasing with the increase in life expectancy ${ }^{1}$. Aortic valve sclerosis (i.e. aortic valve thickening and calcification without pressure gradient) progresses to haemodynamically significant AS in many patients ${ }^{4}$, and it represents a marker of increased risk for cardiovascular events 5 . For many years, it was believed that AS had a long asymptomatic period, followed by a shorter symptomatic period, usually associated with severe narrowing of the aortic valve orifice. Recent studies have shown that the progression of AS is largely unpredictable in the individual patient: in some cases it may be very slow, in others rather fast ${ }^{4}$.

\section{Pathology of calcific aortic stenosis}

Over the last ten years, the scientific progress in the field of calcific AS progression has been substantial ${ }^{6,7}$. Historically, calcific AS has been associated with passive, age-related valve degeneration. However, recent evidence suggests that it is the result of an active inflammatory process involving biochemical, genetic and humoral factors. The microscopic assessment of both mild and severely affected aortic valves shows endothelial disruption, with underlying subendothelial thickening. The lesion itself contains disorganized collagen fibres, chronic inflammatory cells, lipids, and bone min$\mathrm{eral}^{8}$. These histological findings closely resemble those seen in atherosclerosis and suggest chronic inflammation. The factors that initiate the inflammatory process have not been totally identified. Mechanical injury to the endothelium is thought to facilitate subsequent inflammation. Lipids may penetrate the valvular interstitial tissue and accumulate in the areas of inflammation, due to endothelial injury.

\section{Lipids}

Several factors have been associated with aortic valve stenosis and sclerosis progression, such as advanced patient age, male gender, obesity, smoking, hypertension, diabetes mellitus, coronary artery disease ${ }^{9,10}$. There is clinical evidence of an association between aortic valve lesion and dyslipidaemia, such as increased total serum cholesterol, low-density lipoprotein (LDL), lipoprotein Lp(a) concentration and decreased high-density lipoprotein levels (HDL) ${ }^{10,11}$. The oxidized lipoproteins are cytotoxic and capable of stimulating inflammatory activity and mineralization. Several experimental studies have advanced the understanding of aortic valve disease pathogenesis ${ }^{12,13}$. Rajamannan et al. showed that aortic valves from hypercholesterolaemic rabbits had evidence of atherosclerotic lesions, increased C-reactive protein, early calcification, and lesser levels of nitric oxide synthase compared with controls ${ }^{12}$.
Despite the similarities, AS and atherosclerotic lesions are not the same. For instance, typical smooth muscle cells are not found in diseased aortic valve leaflets while the calcification process is prominent in aortic valve lesions. Furthermore, mineralization occurs earlier in aortic valve lesions than in atherosclerosis. These differences may also explain why most patients with severe AS have significant coronary artery disease while most patients with coronary artery disease do not have $\mathrm{AS}^{8}$.

\section{Genetic factors}

Concerning genetic factors, it has been shown that the vitamin $\mathrm{D}$ receptor genotype predisposes to the development of calcific $\mathrm{AS}^{14}$. Novaro et al. studied the association between apolipoprotein $\mathrm{E}$ alleles and calcific valvular disease, providing evidence for a possible genetic role in aortic valve calcification ${ }^{15}$. A very recent study showed that genetic variation in the Lp (a) locus, mediated by $\mathrm{Lp}$ (a) levels, is associated with aortic valve calcification and incident clinical $\mathrm{AS}^{16}$.

\section{Statin therapy for calcific aortic stenosis?}

\section{Echocardiographic studies}

The old concept of AS as a passive degenerative disease is now obsolete since studies have shown that it actually represents an active process similar to atherosclerosis ${ }^{8}$. This has led to increased interest in searching a medical therapy which can slow the progression of AS.

Over the course of time, several serial echocardiographic studies have evaluated the role of statin treatment on the progression of calcific AS (tables 1,2). Aronow et al. have published a retrospective study showing that, in an old population with mild AS and a LDL plasma concentration $\geq 125 \mathrm{mg} / \mathrm{dL}$, the use of statins significantly reduced the increase in peak systolic gradient across the aortic valve as compared to those untreated $(3.4 \pm 1.0 \text { vs. } 6.3 \pm 1.4 \mathrm{mmHg} / \text { year, } P<0.0001)^{17}$. Novaro et al. showed a slower progression of calcific AS in patients on statin treatment (the annualized decrease in aortic valve area was $0.11 \pm 0.18 \mathrm{~cm}^{2} /$ year for the nonstatin group vs. $0.06 \pm 0.16 \mathrm{~cm}^{2} /$ year in the statin group, $P=0.03)^{18}$. Also, Bellamy et al. found in their study that the use of statins was associated with a slower progression of AS (decrease in aortic valve area $-3 \pm 10 \%$ vs. $-7 \pm 13 \%$ per year, $P=0.04)^{19}$. In 2004, Rosenhek et al. published the results of their retrospective study, showing a significantly lower progression of AS in patients treated with statins (aortic jet velocity, $0.10 \pm 0.41 \mathrm{~m} / \mathrm{s} /$ year) than in those who were not $(0.39 \pm 0.42 \mathrm{~m} / \mathrm{s} /$ year, $P<0.0001)^{20}$. All these retrospective studies have similar 
Table 1 Characteristics of patients included in observational retrospective studies concerning aortic stenosis progression

\begin{tabular}{|c|c|c|c|c|c|c|c|c|c|c|c|}
\hline Authors & PY & $\begin{array}{l}\text { Pts } \\
\text { (N) }\end{array}$ & $\begin{array}{l}\text { Pts receiving } \\
\text { statins } \\
\text { (N) }\end{array}$ & $\begin{array}{l}\text { Duration of } \\
\text { follow-up } \\
\text { (months) }\end{array}$ & $\begin{array}{l}\text { Mean } \\
\text { age (y) }\end{array}$ & $\begin{array}{c}\text { Female } \\
(\%)\end{array}$ & $\begin{array}{l}\text { HT } \\
(\%)\end{array}$ & DM (\%) & CAD (\%) & $\begin{array}{l}V \max \\
(\mathrm{m} / \mathrm{s})\end{array}$ & $\begin{array}{l}\text { Effect of statins } \\
\text { on progression }\end{array}$ \\
\hline Aronow et al. (17) & 2001 & 180 & 62 & 33 & $82 \pm 5$ & 69 & 73 & 27 & - & - & Yes \\
\hline Novaro et al. (18) & 2001 & 174 & 57 & 21 & $68 \pm 12$ & 56 & 69 & 25 & 59 & 2.65 & Yes \\
\hline Bellamy et al. (19) & 2002 & 156 & 38 & 44 & $77 \pm 12$ & 42 & 66 & 24 & 35 & 2.95 & Yes \\
\hline Rosenhek et al. (20) & 2004 & 211 & 50 & 24 & $70 \pm 10$ & 49 & 80 & 21 & 27 & 3.96 & Yes \\
\hline Antonini-Canterin et al. (21) & 2008 & 1,046 & 309 & 228 & $69 \pm 7$ & 42 & 81 & 33 & 78 & 2.2 & $\begin{array}{l}\text { Yes, in Ao sclerosis } \\
\text { and mild AS }\end{array}$ \\
\hline
\end{tabular}

Ao: aortic, AS: aortic stenosis, CAD: coronary artery disease, DM: diabetes mellitus, HT: arterial hypertension, PY: publication year, Pts: patients, Vmax: peak aortic jet velocity.

Empty fields indicate lack of data in the respective studies.

Table 2 Characteristics of patients included in prospective studies concerning aortic stenosis progression

\begin{tabular}{|c|c|c|c|c|c|c|c|c|c|c|c|c|}
\hline Authors & PY & $\begin{array}{l}\text { Pts } \\
\text { (N) }\end{array}$ & $\begin{array}{l}\text { Duration of } \\
\text { follow-up } \\
\text { (months) }\end{array}$ & $\begin{array}{c}\text { AS } \\
\text { definition, } \\
\mathrm{m} / \mathrm{s}\end{array}$ & $\begin{array}{l}\text { Pts in statin } \\
\text { and placebo } \\
\text { groups (N) }\end{array}$ & $\begin{array}{c}\text { Mean age } \\
\text { (yrs) }\end{array}$ & $\begin{array}{c}\text { Female } \\
(\%)\end{array}$ & HT (\%) & $\begin{array}{l}\text { DM } \\
(\%)\end{array}$ & $\begin{array}{l}\text { CAD } \\
(\%)\end{array}$ & $\begin{array}{c}V_{\max } \\
(\%)\end{array}$ & $\begin{array}{l}\text { Effect of } \\
\text { statin on } \\
\text { progression }\end{array}$ \\
\hline \multirow{2}{*}{ Cowell et al. (22) } & \multirow{2}{*}{2005} & \multirow{2}{*}{134} & \multirow{2}{*}{25} & $\geq 2.5$ & 77 & $68 \pm 11$ & 32 & 62 & 4 & 23 & 3.39 & \multirow{2}{*}{ No } \\
\hline & & & & $\{\geq 2.5$ & 78 & $68 \pm 10$ & 28 & 69 & 5 & 27 & 3.45 & \\
\hline \multirow{2}{*}{ Moura et al. (26) } & \multirow{2}{*}{2007} & \multirow{2}{*}{121} & \multirow{2}{*}{18} & $3-4$ & 61 & $73 \pm 8$ & 66 & 74 & 43 & - & 3.65 & \multirow{2}{*}{ Yes } \\
\hline & & & & £3-4 & 60 & $74 \pm 9$ & 40 & 53 & 22 & - & 3.62 & \\
\hline \multirow{2}{*}{ Rossebo et al. (23) } & \multirow{2}{*}{2008} & \multirow{2}{*}{1873} & \multirow{2}{*}{52} & "2.5-4 & 944 & $68 \pm 9$ & 39 & 52 & - & - & 3.09 & \multirow{2}{*}{ No } \\
\hline & & & & $\{2.5-4$ & 929 & $67 \pm 10$ & 39 & 51 & - & - & 3.1 & \\
\hline \multirow{2}{*}{ Dichtl et al. (24) } & \multirow{2}{*}{2008} & \multirow{2}{*}{47} & \multirow{2}{*}{27.6} & ${ }^{*} \geq 2.5$ & 23 & $64 \pm 12$ & 35 & 39 & 4 & 39 & 3.4 & \multirow{2}{*}{ No } \\
\hline & & & & ${ }^{f} \geq 2.5$ & 24 & $70 \pm 10$ & 46 & 58 & 21 & 17 & 3.2 & \\
\hline \multirow{2}{*}{ Chan et al. (25) } & \multirow{2}{*}{2010} & \multirow{2}{*}{269} & \multirow{2}{*}{42} & "2.5-4 & 134 & $58 \pm 14$ & 37 & - & - & - & 3.19 & \multirow{2}{*}{ No } \\
\hline & & & & $\{2.5-4$ & 135 & $58 \pm 13$ & 40 & - & - & - & 3.16 & \\
\hline
\end{tabular}

AS: aortic stenosis, CAD: coronary artery disease, DM: diabetes mellitus, HT: arterial hypertension, PY: publication year, Pts: patients, Vmax: peak aortic jet velocity. Empty fields indicate lack of data in the respective studies.

"statin group, Eplacebo group.

limitations: a small sample size of patients treated with statins, relatively short mean follow-up duration and lack of information about statin efficacy on different degrees of disease severity. In 2008, a large retrospective case-control study showed no significant reduction in AS progression in patients receiving statins ${ }^{21}$. A positive effect of statins was found only in the subgroup of patients with aortic valve sclerosis and mild AS (peak velocity $<3 \mathrm{~m} / \mathrm{s}$ ), suggesting that statin therapy should be taken into consideration in the early stages of this disease.

Because the results of the first published studies were conflicting, several prospective randomized controlled trials were developed to determine whether statins could reduce calcific AS progression in adult patients (table 2). The TASS, the SALTIRE, the large SEAS and the ASTRONOMER trials included patients with mild to severe calcific $\mathrm{AS}^{22-25}$. Their results did not confirm a positive effect of statins in slowing the progression of AS in these patients (table 2). The SALTIRE investigators concluded that intensive lipid-lowering therapy ( $80 \mathrm{mg}$ of atorvastatin) neither halts the progression of calcific AS nor induces its regression, emphasizing that timing of therapy may be the reason for this negative trial. They suggested that earlier initiation of statin therapy may be the key to success in the future. The only prospective but non-randomized study to demonstrate a positive effect of statins on reducing AS progression was the RAAVE trial ${ }^{26}$. The aim was to assess the effect of statin therapy on the haemodynamic progression of calcific moderate to severe AS and on the inflammatory biomarkers that have been described clinically to affect the aortic valve endothelium. These patients received LDL cholesterol treatment with rosuvastatin according to the NCEP-ATPIII guidelines. During a mean follow-up of $73 \pm 24$ weeks, the change in aortic valve area in the control group was $-0.10 \pm 0.09 \mathrm{~cm}^{2} /$ year vs. $-0.05 \pm 0.12 \mathrm{~cm}^{2} /$ year 
in the rosuvastatin group. Prospective therapy with rosuvastatin by targeting serum LDL did slow the progression of echocardiographic parameters of AS and improved the inflammatory biomarkers and vascular end points. This was the first prospective study to show clinical evidence for targeted therapy in asymptomatic moderate to severe AS. In a subgroup analysis, the ASTRONOMER trial identified aortic valve calcification as an independent factor associated with increased AS progression, after correcting for age, baseline AS severity and tricuspid aortic valve morphology ${ }^{25}$. The results showed that in patients with bicuspid aortic valves disease progression is more severe and more aggressive than in tricuspid valves, suggesting careful attention to clinical decisions in patients with bicuspid valve disease. Recently, the hypothesis of statin therapy slowing AS progression was evaluated in congenital AS in the PROCAS trial ${ }^{27}$. This study included 63 patients (age range $18-45$ years). Treatment with rosuvastatin $(10 \mathrm{mg}$ daily) did not slow AS progression in this study ${ }^{27}$.

\section{Experimental studies}

Epidemiological data have also associated accelerated AS progression with low HDL-cholesterol levels and high total cholesterol:HDL-cholesterol ratio, thereby suggesting impaired reverse cholesterol transport as a potential therapeutic target in the treatment of AS. The benefits of HDL/ApoA-I-based interventions in atherosclerotic disease have been well established by several clinical and preclinical studies. Recently, short-term rApoA-IM infusions lead to a rapid reversal of experimental AS and reduce valve inflammation and calcifica$\operatorname{tion}^{28}$.

\section{STATINS AND AORTIC BIOPROSTHETIC VALVES}

Bioprosthetic valve replacement has improved the outcomes of patients with $\mathrm{VHD}^{29}$. A wide variety of prostheses, including mechanical, biological and human tissue, are currently available for clinical use. Mechanical valves have a substantial risk of thromboembolism and thrombotic obstruction and they, therefore, require chronic anticoagulation therapy, which is associated with an increased risk of haemorrhagic complications. Biological prostheses today offer a reliable and effective solution for valve replacement, without the need for anticoagulation, and better haemodynamics as compared to the mechanical substitutes. Bioprostethic valve degeneration, however, remains a critical issue and represents the most frequent cause of reoperation. Therefore bioprostheses are preferable in elderly patients and mechanical ones in young patients. Current data show that pericardial valves are probably superior to porcine valves for aortic valve replacement ${ }^{30}$.

\section{Pathogenesis of bioprosthetic heart valve dysfunction}

The pathogenesis of calcification of bioprosthetic heart valves is less well understood than that of the native aortic valve. There is strong evidence suggesting that the calcification and remodelling of the native aortic valve is an atherosclerotic-like process ${ }^{9}$. Similarly, it has been suggested that elevated lipid levels may influence bioprosthetic valve degeneration ${ }^{31}$. Rajamannan et al. published a recent study proving that bioprosthetic valve deterioration is an active atherosclerosis-like process ${ }^{32}$. Lorusso et al. found that atorvastatin significantly attenuated the post-implant structural degeneration of artificial valve bovine pericardial tissue in a subcutaneous animal model ${ }^{33}$. The difference in lifespan of bioprosthetic valves compared with their native counterparts might be explained by the different underlying pathophysiological process. As bioprostheses are "foreign bodies", the degree of inflammation present in a biological prosthesis may be higher than in native valves. Also, bioprosthetic valves are usually associated with higher transvalvular gradients and haemodynamic stress as compared to native valves. More intense inflammation and higher shear stress of the biological valve may lead to a faster progression of degenerative lesions, prosthesis dysfunction and, ultimately, need for replacement.

\section{Statin therapy for preventing aortic bioprosthesis degeneration?}

\section{Echocardiographic studies}

Whether the modification of atherosclerotic risk factors, such as the use of statins, alters the natural history of bioprosthesis degeneration is unknown. Previous studies have suggested that elevated lipid levels may be associated with faster progression of bioprosthesis degeneration $^{34,35}$. Nollert et al. assessed the influence of cardiovascular risk factors on the degeneration of the aortic Hancock pericardial bioprosthesis ${ }^{34}$. This valve has since been removed from the market due to its early structural failure. Within a younger subgroup of their 161 patient cohort, history of smoking, diabetes mellitus and hyperlipidaemia were associated with the need for reoperation. Farivar and Cohn have also evaluated the impact of hypercholesterolaemia on bioprosthetic valve calcification and the need for reoperation ${ }^{29}$. Their study did not corroborate all the findings by Nollert and 
colleagues but also suggested that cholesterol plays a role in the degeneration of a first-generation porcine bioprosthesis. In a subgroup of 66 patients, they performed a case-control analysis of the tissue valves explanted and compared them with an age- and positionmatched group of 66 patients with similar duration of implantation. The mean serum cholesterol level in the explanted valve group was higher than that of the group whose valves did not require explantation (189 vs $163 \mathrm{mg} / \mathrm{dl}, P<0.0001)^{29}$. David and Ivanov ${ }^{35}$ analysed the large databases from Stanford University and Toronto General Hospital. They did not confirm a role of hyperlipidaemia in predicting freedom of reoperation after aortic valve replacement with bioprosthetic valves. However, it is possible that the degeneration of bioprostheses in patients with atherosclerotic risk factors was reduced because most of them were actually taking statins. Another retrospective study examined the effect of statin treatment on bioprosthetic aortic valve degeneration $^{36}$. The results showed that patients receiving statins had less progression of bioprosthetic valve degeneration than those without statin treatment. This included a slower increase in trans-prosthetic mean gradient $(0.54 \pm 1.03$ vs. $2.47 \pm 4.31 \mathrm{~mm} \mathrm{Hg} /$ year, $P<0.001)$, a slower decline in indexed effective orifice area $\left(0.019 \pm 0.031\right.$ vs. $0.056 \pm 0.086 \mathrm{~cm}^{2} / \mathrm{m}^{2} /$ year, $\left.P<0.001\right)$, and less worsening of aortic regurgitation $(9.1 \%$ vs. $33.1 \%, P=0.022)$ in patients treated with statins vs. those not treated. A combined parameter of prosthetic degeneration progression (either an annual rate of increase in peak velocity of $0.3 \mathrm{~m} / \mathrm{s} /$ year or worsening of aortic regurgitation) was found more frequently in the group without statins. Briand et al. showed in their study that patients with aortic bioprostheses who had the metabolic syndrome developed a faster progression of trans-prosthetic gradient and more prosthetic valve regurgitation as compared with patients who did not have the metabolic syndrome ${ }^{31}$. In contrast to the studies listed above, Gring et al. have reported no association between hyperlipidaemia and either bioprosthesis degeneration or the need for reoperation ${ }^{37}$. Another recent retrospective observational study in 1,193 patients who underwent aortic valve replacement with current generation bioprostheses (mean follow-up period of $4.5 \pm 3.1$ years) did not demonstrate a slowing of bioprosthesis deterioration after receiving statin therapy ${ }^{38}$. The annualized linear rate of peak gradient progression following valve replacement was similar between the groups $(1.0 \pm 12.9$ vs. $2.0 \pm 12.1 \mathrm{mmHg} /$ year, statin vs. no statin, $P=0.52$ ). There were also no differences with respect to aortic regurgitation progression. The authors concluded that the structural durability of current bioprostheses could be the best explanation for their findings.

\section{STATINS AND RHEUMATIC VALVE DISEASE}

\section{Epidemiology and pathology}

Although infrequent in the industrialized world, rheumatic heart disease (RHD) remains a major health problem worldwide and will continue to be encountered in most cardiology practices. Acute rheumatic fever (ARF) is characterized by an abnormal immune response to infection with rheumatogenic group A streptococci. Associations with certain human leukocyte antigen types, abnormal T-cell activation and infiltration, and the presence of B-cells with a distinctive alloantigen (d8/17) have been identified in ARF patients, along with genetic variations in tumour necrosis factor alpha ${ }^{39}$. ARF leads to an acute valvulitis with inflammation and oedema of the leaflets. Fibrin-platelet thrombi occur along the leaflet contact zones, and the fibrosis of the affected valves leads to deformity, stenosis and/or insufficiency. The progression to manifest RHD, particularly the calcification that accompanies RHD, was, until recently, thought to be a passive process. Recent studies, however, have shown that progression of RHD is the result of an organized inflammatory process associated with the expression of osteoblast markers and neoangiogenesis ${ }^{40}$.

\section{Statin therapy for rheumatic valve disease?}

\section{Echocardiographic studies}

If indeed RHD is an inflammatory disease, then statins may have a role in preventing progression of the disease. There are few data about the role of statins in patients with rheumatic valvular disease. A retrospective echocardiography-based study including 164 patients with rheumatic AS of which 134 received statins, evaluated the effect of statins on the long-term haemodynamic progression of $\mathrm{AS}^{41}$. Specifically, the annual change in peak aortic velocity was lower in those treated with statins than those not treated $(0.05 \pm 0.07 \mathrm{~m} / \mathrm{s} /$ year vs. $0.12 \pm 0.11 \mathrm{~m} / \mathrm{s} /$ year, $P=0.001)$. Moreover, rapid progression (annual rate of $\geq 0.10 \mathrm{~m} / \mathrm{s}$ ) was found in almost one-half of the patients not receiving statins but only in $10 \%$ of the statin-treated patients. Mean follow-up was 8.5 years, thereby providing relatively long-term data with promising results about the role of statins in reducing the progression of rheumatic AS. Another study assessed the effects of statin treatment in slowing the progression of rheumatic mitral valve disease ${ }^{42}$. In rheumatic mitral stenosis statins reduced the rate of decrease in the mitral valve area $\left(0.027 \pm 0.056\right.$ vs. $0.067 \pm 0.082 \mathrm{~cm}^{2} /$ year, $P=0.005$ ) and the prevalence of fast mitral stenosis progression. Fewer patients had an increase in systolic 
pulmonary artery pressure higher than $10 \mathrm{mmHg}$ over the mean follow-up period of $6.1 \pm 4.0$ years. These results confirm the potential role of statin treatment in slowing the progression of rheumatic valve disease.

\section{DISCUSSION}

\section{Aortic valve sclerosis, aortic valve stenosis and atherosclerosis: the same disease?}

Why did most retrospective studies find statins to be effective in reducing AS progression while prospective trials have consistently demonstrated the contrary? First, in the retrospective studies, statins were used in the setting of hypercholesterolaemia, whereas in the prospective randomized trials patients with hypercholesterolaemia were generally excluded. This can also explain the positive findings of the prospective but non-randomized RAAVE trial, in which only AS patients with hypercholesterolaemia were treated with rosuvastatin ${ }^{26}$. In fact, the population of the majority of prospective studies does not reflect the "real world" in which "pure" calcific AS without any "atherosclerotic" co-morbidity is very rare and possibly based on other pathogenetic mechanisms. It may be argued that lipid-lowering treatment is unlikely to influence disease progression in the presence of calcific AS. The more advanced stage of AS at the time of enrolment in the SALTIRE ${ }^{23}$ population could be another explanation for its negative result. Patients with peak aortic velocities below $2.5 \mathrm{~m} / \mathrm{s}$ were excluded from all the prospective studies. Thus, the results of these studies cannot clarify the role of statin treatment in the early stages of aortic valve disease (i.e. aortic sclerosis). Intervening at this earlier stage of the disease process may be more beneficial. This hypothesis has been suggested by the results of a large retrospective study, showing that the effect of statins seems stage-related ${ }^{21}$. Thus, statins had a positive effect only in patients with aortic sclerosis and mild AS statins had a positive effect ${ }^{21}$. Aortic valve stenosis and sclerosis are morphologically different: in aortic valve sclerosis there is a deposition of lipids, which are oxidized similarly to atherosclerosis, whereas in advanced AS, there is mainly calcium overgrowth, which may have its own determinants, independent of cholesterol levels. This could explain the differences in statin treatment effect between patients with advanced AS and those with aortic valve sclerosis. This hypothesis is also supported by the observation that statins significantly slow the growth of non-calcified coronary plaques, but do not affect the growth rate of mixed or calcified ones ${ }^{43}$. Statins may influence the natural history of the disease primarily in patients with hyperlipidaemia, after prolonged use, initiated in an early phase of valvular leaflet thickening (i.e. aortic sclerosis). Further prospective studies on the role of statins in patients with aortic sclerosis or mild AS without significant calcifications are needed to evaluate whether the indication of statin treatment should be extended to this group of patients. However, patients with aortic valve sclerosis do not commonly present for routine cardiology testings, thus their identification would require population screening.

\section{A medical therapy for aortic valve sclerosis?}

We believe the jury is still out on the debate about the role of statin treatment in VHD. The answer is still uncertain, considering also recently published studies providing new information with future implications for the treatment of this disease process. Re-evaluation of the underlying pathophysiology is therefore required so that novel therapeutic strategies can be developed. It has been shown that Lrp5, the LDL co-receptor, regulates calcification in the aortic valve and the aorta ${ }^{44}$. Experimental studies have evolved into a series of clinical parameters, which provide the foundation for an algorithm to treat aortic valve disease: the LDL-densityradius and the LDL-density-pressure theories ${ }^{44}$. The LDL-density theories provides information on the role of Lrp 5/6 receptor biology in the treatment of calcific aortic valve disease. The LDL-density-radius theory assumes that the initiating event in AS is atherosclerosis, giving the possibility for medical therapy for AS. This takes into account two fundamental differences in vascular versus valvular biology: the first is calculating the magnitude of LDL lowering, and the second is the difference in radius between the aortic valve and that of the vessel. The LDL-density-pressure theory accounts for the haemodynamic pressure differential, which regulates the Lrp 5/6 receptors. In experimental hypercholesterolaemia the left-sided heart valves (aortic and mitral), developed the atherosclerotic lesion and not the rightsided heart valves (pulmonic and tricuspid) ${ }^{44}$. The other non-lipid-lowering effect of statins in the vasculature is the improvement in endothelial function via modulation of endothelial nitric oxide synthase. Rajamannan et al. have shown modulation of endothelial nitric oxide synthase enzymatic activity in the aortic valve of the experimental model of valve atherosclerosis ${ }^{12}$.

A very recent study emphasized the genetic contribution to aortic valve calcification. The authors found that genetic variations in the LPA locus, mediated by $\mathrm{Lp}$ (a) levels, is associated with calcific $\mathrm{AS}^{16}$. This recent theory has a great impact on the development of the medical treatment of AS. Lp(a) is a cholesterol rich particle consisting of a covalently linked molecule of apolipoprotein B100 with a molecule of apolipoprotein (a). $\operatorname{Lp}(\mathrm{a})$ has long been considered a risk factor for 
coronary artery disease. An association between increased $\mathrm{Lp}(\mathrm{a})$ levels and aortic valve disease has been evaluated in previous studies ${ }^{11}$. Lp(a) has been shown to accumulate in both aortic sclerosis and severe AS. Given this evidence of a relationship between $\operatorname{Lp}(\mathrm{a})$ and calcific AS, further studies are needed to evaluate whether lowering Lp(a) levels in early stage AS (i.e. with niacin), will reduce the incidence or progression of aortic valve disease.

\section{Statins and aortic bioprostheses}

Biological prostheses are a model of accelerated degeneration of valve tissue commonly available in clinical practice. The proportion of aortic bioprostheses will increase in the future as the population grows older and the incidence of AS is increasing. Finding a way to slow the progression of degenerative changes in bioprosthetic valves would have a great clinical and social impact. Aortic valve prostheses most often behave haemodynamically like a mildly stenotic native valve. This similarity could explain a similar benefit of statin treatment in the prevention of aortic bioprosthesis degeneration, but there is no definitive proof yet. There are no prospective randomized trials to date addressing the role of statin therapy in these patients (table 3 ). The potential impact can be very important considering not only the ever increasing number of older patients needing valve replacement surgery, but also in light of the newer percutaneous procedures. The transcatheter aortic valve implants emerged as a solution for severe AS patients ineligible for open-heart surgery ${ }^{2}$. The initial results are promising, but data on the long-term durability of such valves is still missing, and this is also one of the aspects preventing the expansion of current indications for this procedure to other patients with AS. In the future, the indications for transcatheter aortic valve implants could be expanded and the possibility of having a medical therapy that prevents bioprosthesis degeneration could be of major interest.

\section{Statins and rheumatic valve disease}

Concerning RHD, the retrospective studies addressing the role of statins in rheumatic mitral and aortic stenosis included mild to moderate mitral and mild aortic

Table 3 Published studies evaluating the association between cholesterol levels and statin therapy in bioprosthetic valve degeneration

\begin{tabular}{|c|c|c|c|c|}
\hline Author & Year & Study type & Results & Comments \\
\hline $\begin{array}{l}\text { David and Ivanov } \\
\text { (35) }\end{array}$ & 2003 & $\begin{array}{l}\text { Retrospective } \\
\text { cohort study }\end{array}$ & $\begin{array}{l}\text { The only significant } \\
\text { independent predictor of reoperation was age; } \\
\text { hyperlipidaemia was not significant. }\end{array}$ & $\begin{array}{l}\text { Most of the patients were taking statins, determining a } \\
\text { reduced probability of valve failure in patients with } \\
\text { cardiovascular risk factors. }\end{array}$ \\
\hline Farivar and Cohn (29) & 2003 & $\begin{array}{l}\text { Retrospective } \\
\text { cohort study with } \\
\text { case-control analysis }\end{array}$ & $\begin{array}{l}\text { The mean serum cholesterol level of the explanted } \\
\text { valve group was significantly higher than that } \\
\text { of the group whose valves did not require explantation }\end{array}$ & $\begin{array}{l}\text { Increased serum cholesterol level may be a risk factor } \\
\text { for bioprosthetic valve calcification requiring } \\
\text { explantation. However, the study was criticized } \\
\text { because first generation bioprostheses are more } \\
\text { susceptible for degeneration. }\end{array}$ \\
\hline Nollert et al (34) & 2003 & $\begin{array}{l}\text { Retrospective } \\
\text { cohort study }\end{array}$ & $\begin{array}{l}\text { In patients aged } 57 \text { years or younger, diabetes mellitus, } \\
\text { female sex, cigarette smoking, and high cholesterol } \\
\text { and triglyceride levels were associated with accelerated } \\
\text { valve failure. }\end{array}$ & $\begin{array}{l}\text { The studied patients received Hancock pericardial } \\
\text { valves that have been removed from the market. }\end{array}$ \\
\hline $\begin{array}{l}\text { Antonini-Canterin et al } \\
\text { (36) }\end{array}$ & 2003 & $\begin{array}{l}\text { Retrospective } \\
\text { cohort study }\end{array}$ & $\begin{array}{l}\text { Statin use was associated with slowing progression and } \\
\text { a lower proportion of prosthesis degeneration. }\end{array}$ & $\begin{array}{l}\text { The main limitation of the study is the retrospective } \\
\text { study type. }\end{array}$ \\
\hline Gring et al (37) & 2006 & $\begin{array}{l}\text { Prospective } \\
\text { non randomized }\end{array}$ & $\begin{array}{l}\text { Preoperative cholesterol levels did not predict } \\
\text { structural valve degeneration in patients undergoing } \\
\text { bioprosthetic aortic valve replacement. }\end{array}$ & $\begin{array}{l}\text { In multivariate analysis, only younger age, increased } \\
\text { body weight, creatinine level and pericardial valve } \\
\text { predicted bioprosthesis degeneration. }\end{array}$ \\
\hline Shetty et al (45) & 2009 & $\begin{array}{l}\text { Retrospective } \\
\text { observational study }\end{array}$ & $\begin{array}{l}\text { Immunohistochemistry showed the presence of } \\
\text { oxidized low-density lipoprotein and } \\
\text { glycosaminoglycans in the fibrosa layer of } 13 \text { of the } 18 \\
\text { bioprosthetic valves explanted. Their results support } \\
\text { the concept that lipid-mediated inflammatory } \\
\text { mechanisms may contribute to the degeneration of } \\
\text { bioprostheses. }\end{array}$ & $\begin{array}{l}\text { Limitations of the study: the duration of statin } \\
\text { treatment was not collected, so it could not assess } \\
\text { whether lipid-lowering therapy may have provided } \\
\text { protection against lipid accumulation in bioprostheses; } \\
\text { a substantial proportion of patients ( } 28 \% \text { ) had no } \\
\text { accumulation of lipids within their bioprostheses, } \\
\text { suggesting that other mechanisms also contribute to } \\
\text { their degeneration. }\end{array}$ \\
\hline Kulik et al (38) & 2010 & $\begin{array}{l}\text { Retrospective } \\
\text { observational study }\end{array}$ & $\begin{array}{l}\text { The results showed no association between early } \\
\text { postoperative statin therapy and slowing of } \\
\text { bioprosthesis degeneration. }\end{array}$ & $\begin{array}{l}\text { The main strengths of the study are: the largest number } \\
\text { of patients included and the use of contemporary } \\
\text { prostheses. }\end{array}$ \\
\hline
\end{tabular}


stenosis, respectively. However, limitations result from the retrospective nature of these studies. Three main processes appear to play roles in the progression of mitral stenosis: recurrent episodes of carditis, cardiovascular risk factors and cellular signalling pathways to differentiate the valve into the osteoblast phenotype $e^{39}$. The future management of the RHD process will incorporate the understanding of these different mechanisms. If the physician can define the traditional risk factors in patients with rheumatic valve disease, targeting those risk factors may slow progression of the lesion.

\section{CONCLUSIONS}

Finding a medical treatment capable of preventing VHD progression is still a hot topic, due to the important clinical implications. Large, prospective randomized trials are needed to properly evaluate the role of statins in the early stages of valvular heart disease. In order to well-design these prospective studies, it is necessary to: - clearly define the selection criteria and using appropriate methods of recruitment, so that patients with aortic sclerosis and mild aortic stenosis can be identified and included in the study;

- identify subjects with and without dyslipidaemia;

- identify subjects with and without active inflammatory markers.

A preventive therapy, which could influence not only the haemodynamic progression of valve disease, but also the cardiovascular outcome, is warranted.

\section{CONFLICT OF INTEREST: none declared.}

\section{REFERENCES}

1. Nkomo VT, Gardin JM, Skelton TN, Gottdiener JS, Scott CG,

Enriquez-Sarano M. Burden of valvular heart diseases: a population-based study. Lancet 2006; 368: 1005-11.

2. Vahanian A, Alfieri O, Andreotti F, Antunes MJ, Baron-Esquivias $\mathrm{G}$, Baumgartner $\mathrm{H}$ Borger MA, Carrel TP, DeBonis M, Evangelista A, Falk V, Lung B, Lancellotti $P$, Pierard L, Price S, Schafers HJ, Schuler G, Stepinska J, Swedberg K, Takkenberg J, Von Oppell UO, Windecker S, Zamorano JL, Zembala M. The Joint Task Force on the Management of Valvular Heart Disease of the European Society of Cardiology (ESC) and the European Association for Cardio-Thoracic Surgery (EACTS). Guidelines on the management of valvular heart disease. Eur Heart J 2012; 33: 2451-96.

3. lung B, Baron G, Butchart EG, Delahaye F, Gohlke-Bärwolf C, Levang OW, Tornos P, Vanoverschelde JL, Vermeer F, Boersma $E_{\text {, }}$ Ravaud P, Vahanian A. A prospective survey of patients with valvular heart disease in Europe: The Euro Heart Survey on Valvular Heart Disease. Eur Heart J 2003; 24: 1231-43.

4. Faggiano $P$, Antonini-Canterin F, Erlicher $A$, Romeo C, Cervesato E, Pavan D, Piazza R, Huang G, Nicolosi GL. Progression of aortic valve sclerosis to aortic stenosis. Am J Cardiol 2003; 91: 99-101.

5. Nightingale AK, Horowitz JD. Aortic sclerosis: not an innocent murmur but a marker of increased cardiovascular risk. Heart 2005; 91: 1389-93.

6. Rajamannan NM, Subramaniam M, Rickard D, Stock SR, Donovan J, Springett M, Orszulak T, Fullerton DA, Tajik AJ, Bonow RO, Spelsberg T. Human aortic valve calcification is associated with an osteoblast phenotype. Circulation 2003; 107: 2181-4.

7. Rosenhek R, Binder T, Porenta G, Lang I, Christ G, Schemper M, Maurer G,
Baumgartner $\mathrm{H}$. Predictors of outcome in severe asymptomatic aortic stenosis. N Engl J Med 2000; 343: 611-7.

8. Otto CM, Kuusisto J, Reichenbach DD, Gown AM, O'Brien KD. Characterization of the early lesion of degenerative valvular aortic stenosis. Histological and immunohistochemical studies. Circulation 1994; 90: 844-53.

9. Nassimiha D, Aronow WS, Ahn C, Goldman ME. Association of coronary risk factors with progression of valvular aortic stenosis in older persons. Am J Cardiol 2001; 87: 1313-4.

10. Pohle K, Maffert R, Ropers D, Moshage W, Stilianakis N, Daniel WG, Achenbach S. Progression of aortic valve calcification: association with coronary atherosclerosis and cardiovascular risk factors. Circulation 2001; 104: 1927-32.

11. Gotoh T, Kuroda T, Yamasawa M, Nishinaga M, Mitsuhashi T, Seino Y, Nagoh N, Kayaba K, Yamada S, Matsuo H. Correlation between lipoprotein (a) and aortic valve sclerosis assessed by echocardiography (the JMS Cardiac Echo and Cohort Study). Am J Cardiol 1995; 76: 928-32.

12. Rajamannan NM, Subramaniam M, Stock SR, Stone NJ, Stone NJ, Springett M, Ignatiev KI, McConnell JP, Singh RJ, Bonow RO, Spelsberg TC. Atorvastatin inhibits calcification and enhances nitric oxide synthase production in the hypercholesterolaemic aortic valve. Heart 2005; 91: 806-10.

13. Roosens B, Bala G, Droogmans S, Van Camp G, Breyne J, Cosyns B. Animal models of organic heart valve disease. Int J Cardiol 2013; 165: 398-409.

14. Ortlepp JR, Hoffmann R, Ohme F, Lauscher J, Bleckmann F, Hanrath P. The vitamin D receptor genotype predisposes to the development of calcific aortic valve stenosis. Heart 2001; 85: 635-8.
15. Novaro GM, Sachar R, Pearce GL, Sprecher DL, Griffin BP. Association between apolipoprotein $\mathrm{E}$ alleles and calcific valvular heart disease. Circulation 2003; 108: 1804-8.

16. Thanassoulis G, Campbell C, Owens D, Smith JG, Smith AV, Peloso GM, Kerr KF, Pechlivanis S, Budoff MJ, Harris TB, Malhotra R, O'Brien KD, Kamstrup PR, Nordestgaard BG, Tybjaerg-Hansen A, Allison MA, Aspelund T, Criqui MH, Heckbert SR, Hwang SJ, Liu Y, Sjogren M, van der Pals J, Kälsch H, Mühleisen TW, Nöthen MM, Cupples LA, Caslake M, Di Angelantonio E, Danesh J, Rotter Jl, Sigurdsson S, Wong Q, Erbel R, Kathiresan S, Melander O, Gudnason V, O'Donnell CJ, Post WS ; CHARGE Extracoronary Calcium Working Group. Genetic associations with valvular calcification and aortic stenosis. NEngl J Med 2013; 368: 503-12.

17. Aronow WS, Ahn C, Kronzon I, Goldman ME. Association of coronary risk factors and use of statins with progression of mild valvular aortic stenosis inolder persons. Am J Cardiol 2001; 88: 693-5.

18. Novaro GM, Tiong IY, Pearce GL, Lauer MS, Sprecher DL, Griffin BP. Effect of hydroxymethylglutaryl coenzyme A reductase inhibitors on the progression of calcific aortic stenosis. Circulation 2001; 104: 2205-9.

19. Bellamy MF, Pellikka PA, Klarich KW, Tajik AJ, Enriquez-Sarano M. Association of cholesterol levels, hydroxymethylglutaryl coenzyme-A reductase inhibitor treatment, and progression of aortic stenosis in the community. J Am Coll Cardiol 2002; 40: 1723-30.

20. Rosenhek R, Rader F, Loho N, Gabriel H, Heger M, Klaar U, Schemper M, Binder T, Maurer G, Baumgartner $\mathrm{H}$. Statins but not angiotensin-converting enzyme inhibitors delay progression of aortic stenosis. Circulation 2004; 110: 1291-5. 
21. Antonini-Canterin F, Hirsu M, Popescu BA, Leiballi E, Piazza R, Pavan D, Ginghină C, Nicolosi GL. Stage-related effect of statin treatment on the progression of aortic valve sclerosis and stenosis.

Am J Cardiol 2008; 102: 738-42.

22. Cowell SJ, Newby DE, Prescott RJ, Bloomfield P, Reid J, Northridge DB, Boon NA A randomized trial of intensive lipid-lowering therapy in calcific aortic stenosis. N Engl J Med 2005; 352: 2389-97.

23. Rossebo AB, Pedersen TR, Boman $K$, Brudi $P$, Chambers JB, Egstrup K, Gerdts E, Gohlke-Bärwolf C, Holme I, Kesäniemi YA, Malbecq W, Nienaber CA, Ray S, Skjaerpe T, Wachtell K, Willenheimer R. Intensive lipid lowering with simvastatin and ezetimibe in aortic stenosis. N Engl J Med 2008; 359: 1343-56.

24. Dichtl W, Alber HF, Feuchtner GM, Hintringer $F_{t}$ Reinthaler M, Bartel T, Süssenbacher A, Grander W, Ulmer H, Pachinger O, Müller S. Prognosis and risk factors in patients with asymptomatic aortic stenosis and their modulation by atorvastatin $(20 \mathrm{mg})$. Am J Cardiol 2008; 102: 743-8.

25. Chan KL, Teo K, Dumesnil JG, Ni A, Tam J. Effect of lipid lowering with rosuvastatin on progression of aortic stenosis: results of the aortic stenosis progression observation: measuring effects of rosuvastatin (ASTRONOMER trial). Circulation 2010; 121: 306-14.

26. Moura L, Ramos S, Zamorano JL, Barros IM, Azevedo LF, Rocha-Gonçalves F, Rajamannan NM. Rosuvastatin affecting aortic valve endothelium to slow the progression of aortic stenosis. J Am Coll Cardiol 2007; 49: 554-61.

27. Van der Linde D, Yap SC, Van Dijk AP, Budts W, Pieper PG, van der Burgh PH, Mulder BJ, Witsenburg M, Cuypers JA, Lindemans J, Takkenberg JJ, Roos-Hesselink JW. Effects of rosuvastatin on progression of stenosis in adult patients with congenital aortic stenosis (PROCAS trial). Am J Cardiol 2011; 108: 265-71.

28. Speidl WS, Cimmino G, Ibanez B, Elmariah S, Hutter R, Garcia MJ, Fuster V, Goldman ME, Badimon JJ. Recombinant apolipoprotein A-I Milano rapidly reverses aortic valve stenosis and decreases leaflet inflammation in an experimental rabbit model. Eur Heart J 2010; 31: 2049-57.
29. Farivar RS, Cohn LH. Hypercholesterolemia is a risk factor for bioprosthetic valve calcification and explantation. J Thorac Cardiovasc Surg 2003; 126: 969-75.

30. Rahimtoola SH. Choice of prosthetic heart valve for adult patients. J Am Coll Cardiol 2003; 41: 893-904.

31. Briand $M$, Pibarot $P$, Despres JP, Voisine $P$, Dumesnil JG, Dagenais F, Mathieu P. Metabolic syndrome is associated with faste degeneration of bioprosthetic valves. Circulation 2006; 114(1 Suppl): I512-7.

32. Rajamannan NL, Evans F, Aikawa E, Grande-Allen KJ, Demer LL, Heistad DD, Simmons CA, Masters KS, Mathieu P, O'Brien KD, Schoen FJ, Towler DA, Yoganathan AP, Otto CM. Calcific aortic valve disease: not simply a degenerative process. Circulation 2011; 124: 1783-91.

33. Lorusso R, Corradi D, Maestri R, Bosio S, Curulli A, Beghi C, Gerometta P, Russo C, Gelsomino S, Moreo A, De Cicco G, Rosano G, Volterrani M. Atorvastatin attenuates post-implant tissue degeneration of cardiac prosthetic valve bovine pericardial tissue in a subcutaneous animal model. Int J Cardiol 2010; 141: 68-74.

34. Nollert G, Miksch J, Kreuzer E, Reichart B. Risk factors for atherosclerosis and the degeneration of pericardial valves after aortic valve replacement. J Thorac Cardiovasc Surg 2003; 126: 965-8.

35. David TE, Ivanov J. Is degenerative calcification of the native aortic valve similar to calcification of bioprosthetic heart valves? J Thorac Cardiovasc Surg 2003; 126: 939-41.

36. Antonini-Canterin F, Zuppiroli A, Popescu BA, Granata G, Cervesato E, Piazza R, Pavan D, Nicolosi GL. Effect of statins on the progression of bioprosthetic aortic valve degeneration. Am J Cardiol 2003; 92: 1479-82.

37. Gring CN, Houghtaling P, Novaro GM, Roselli E, Smedira N, Banbury M, Blackstone E, Griffin BP. Preoperative cholesterol levels do not predict explant for structural valve deterioration in patients undergoing bioprosthetic aortic valve replacement. $J$ Heart Valve Dis 2006; 15: 261-8.

38. Kulik A, Masters RG, Bedard P, Hendry PJ Lam BK, Rubens F, Mesana TG, Ruel M. Postoperative lipid-lowering therapy and bioprosthesis structural valve deterioration: justification for a randomised trial? Eur J Cardiothorac Surg 2010; 37: 139-44.
39. Rajamannan NM, Antonini-Canterin F, Moura L, Zamorano JL, Rosenhek RA, Best PJ, Lloyd MA, Rocha-Goncalves F, Chandra S Alfieri O, Lancellotti P, Tornos P, Baliga RR Wang A, Bashore T, Ramakrishnan S, Spargias K, Shuvy M, Beeri R, Lotan C, Suwaidi JA, Bahl V, Pierard LA, Maurer G, Nicolosi GL, Rahimtoola SH, Chopra K, Pandian NG. Medical therapy for rheumatic heart disease: is it time to be proactive rather than reactive? Indian Heart J 2009; 61: 14-23.

40. Rajamannan NM, Nealis TB, Subramaniam M, Pandya S, Stock SR, Ignatiev Cl, Sebo TJ, Rosengart TK, Edwards WD, McCarthy PM, Bonow RO, Spelsberg TC. Calcified rheumatic valve neoangiogenesis is associated with vascular endothelial growth factor expression and osteoblast-like bone formation. Circulation 2005; 111: 3296-301.

41. Antonini-Canterin F, Leiballi E, Enache $R$, Popescu BA, Roşca M, Cervesato E, Piazza R, Ginghină C, Nicolosi GL. Hydroxymethylglutaryl coenzyme-A reductase inhibitors delay the progression of rheumatic aortic valve stenosis: a long-term echocardiographic study. J Am Coll Cardiol 2009; 53: 1874-9.

42. Antonini-Canterin F, Moura LM, Enache R, Leiballi E, Pavan D, Piazza R, Popescu BA, Ginghina C, Nicolosi GL, Rajamannan NM. Effect of hydroxymethylglutaryl coenzyme-a reductase inhibitors on the long-term progression of rheumatic mitral valve disease. Circulation 2010; 121: 2130-6.

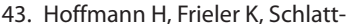
mann P, Hamm B, Dewey M. Influence of statin treatment on coronary atherosclerosis visualised using multidetector computed tomography. Eur Radiol 2010; 20: 2824-33.

44. Rajamannan NM, Subramaniam M, Caira F, Stock SR, Spelsberg TC. Atorvastatin inhibits hypercholesterolemia-induced calcification in the aortic valves via the Lrp5 receptor pathway. Circulation 2005; 112: 1229-34.

45. Shetty R, Pibarot $P$, Audet A, Janvier R, Dagenais F, Perron J, Couture C, Voisine P, Després JP, Mathieu P. Lipid-mediated inflammation and degeneration of bioprosthetic heart valves. Eur J Clin Invest 2009; 39: 471-80. 